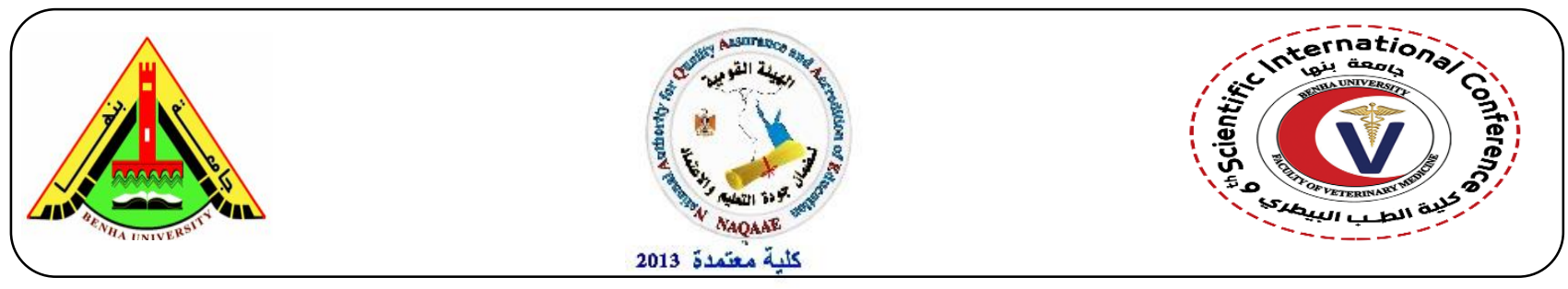

\title{
Control of Histamine Level in Oreochromis Niloticus Fillets Using Essential Oils
}

\author{
Elshafey $^{2}$, Wesam S., Ibrahim, ${ }^{\mathbf{1}}$ Hemmat M., Hassan ${ }^{\mathbf{1}}$ M.A. \& Maarouf, A. $\mathbf{A}^{\mathbf{2}}$.
} 1-Food hygiene Dep., Fac. Vet, Med., Benha Univ. 2- Animal Health Research Institute, Benha.

\section{A B S TR A C T}

It was studied that effect of different essential oils on the histamine level in examined Oreochromis niloticus fillet samples. Accordingly, the addition of essentials oils (cinnamon and Oregano) was applied by (1\%) against control group. The obtained results revealed that histamine levels in control samples increased by $24.8 \% ; 70.1 \%$ and $94.5 \%$ with mean values of $18.84 ; 25.67$, and 29.35 after chilling for $3 ; 6$ and 9 days, respectively; meanwhile, the histamine mean concentration at zero time was $15.09 \mathrm{mg} / \mathrm{kg}$. Concerning addition of cinnamon oil $1 \%$, levels of histamine decreased to $18.7 \% ; 46.6 \%$ and $77.0 \%$ with mean values of $17.92 ; 22.13$, and 26.71 after $3 ; 6$ and 9 days, respectively. In contrast the addition of oregano oil $1 \%$, to the examined $O$. niloticus fillet samples lead to significant decrease in histamine levels by $8.2 \%, 23.9 \%$ and $32.3 \%$ with mean values 16.33 , 18.7 and 19.96 after 3, 6 and 9 days in 4C storage temperature, respectively. Finally, it can have concluded that the addition of oregano oil was superior for control of undesirable histamine in Oreochromis niloticus fillets.

Key words: cinnamon, Oregano, histamine, Oreochromis niloticus fillets.

(http://www.bvmj.bu.edu.eg )

(BVMJ-34(3): 172-177, 2018)

bacterial action. Fish spp. implicated

\section{INTRODUCTION:}

Fish is a great source of protein, vitamins, minerals, omega-3 fatty acids and a key nutrient for brain development. A wellbalanced diet that includes a variety of fish and shellfish can contribute to heart health and children's proper growth and development. (Jaclyn et al., 2010).

Histamine is formed from histidine by are invariably found to be rich in histidine.

When held too long at too high temperature. bacteria proliferate, and histamine is formed.

Most bacteria are capable of histamine production are not part of the normal flora, but represent post-harvest contamination during handling, processing and marketing. Thus, cooling, short storage 
and good handling practices can avoid histamine formation. Histamine may be a reason for low demand for certain spp. in certain areas. As histamine is heat stable, it is sometimes present in high levels in canned fish which is a reason for rejection. (Ababouch,1990).

Histamine is important from the toxicological point of view as it is the causative agents of scombroid fish poisoning and food intolerance. The onset of scombroid poisoning is typically from $10 \mathrm{~min}$ to $1 \mathrm{~h}$ following consumption of fish and can last from $12 \mathrm{~h}$ to a few days. The symptoms are variable and include peppery or metallic taste, oral numbness, headache, dizziness, palpitations, rapid and weak pulse, drop in blood pressure, difficulty in swallowing, and thirst. Also noteworthy are allergy-like symptoms such as hives, rash, flushing, and facial swelling (Maintz and Novak, 2007 and Hungerford, 2010).

Biogenic amines formation in foods can be controlled or prevented primarily by limiting bacterial growth through chilling and freezing. However, for many fishing based populations such measures are not practical; therefore, the other measure is to control BAs levels; such approaches to limit microbial growth is making hydrostatic pressures, irradiation, controlled atmospheric packaging (CAP) or by using food additives, histamine may be degraded potentially by using bacterial amine oxidase or amine negative bacteria (Aishath et al., 2010).In addition, the reduction of BAs contents in foods with efficient method should not affect the food quality and safety (Ercan, 2013).

Essential oils and their components are commercially used as flavoring in food industry; also, it has some anti-microbial and anti-oxidant effects that can be control biogenic amines formation (Tajkarims et al., 2010).

Cinnamon and clove essential oils are more active against gram positive bacteria $(S$. aureus) than gram negative bacteria (E. coli). The effectiveness of essential oils may return to action of essential oils and absence of lipopolysaccharide layer in Gram-positive bacteria which act as effective barrier against any additives. (Amin-Reham, 2014)

Therefore, the objective of this study is control of histamine level in $O$. Niloticus fillets by using of essential oils.

\section{MATERIAL AND METHODS:}

\subsection{Preparation of Oreochromis Niloticus fillets:}

A piece of each of fresh Oreochromis Niloticus fillets (100 g) was cut with a sterile scalpel and put under the UV light in the cabinet for 20 minutes in order to reduce the number of the microorganisms attached to its surface.

\subsection{Essential oil extraction:}

The extraction of active ingredients from dry cinnamon and oregano plants were done according to the technique developed by Tandon and Rane (2008). In brief; the dried plant material was size reduced with milling using hammer mill. Extraction of the plant material was carried out by immersion in absolute methanol for three days with agitation using automatic shaker. Then filtration through a piece of gauze to remove solid plant particles were done, the extract was re-filtered through filter paper to remove fine or colloidal particles from the extract. The enriched extract was concentrated by evaporation of the solvent with heating in water bath at 65 
${ }^{\circ} \mathrm{C}$ until solid mass was obtained. Finally, drying the extract by spreading under shaded area till complete dryness, then stored in the refrigerator until using. Each extract was used for preparation of $1 \%(\mathrm{w} / \mathrm{v})$ solution.

\subsection{Mixing of Oreochromis Niloticus} fillets with essential oils:

Samples were divided into 3 basic groups; the $1^{\text {st }}$ one was untreated (control) which immersed in sterile distilled water for 15 minutes. While the $2^{\text {nd }}$ group was mixed with cinnamon extract $(1 \%)$ for 15 minutes, $3^{\text {rd }}$ group was mixed with Oregano extract $(1 \%)$ for 15 minutes.All samples were examined at zero ,3,6 and 9 days of cold storage at $4^{\circ} \mathrm{C}$.

\subsection{Determination of histamine:}

It is applied by using HPLC as described before.

\subsection{Sensory evaluation:}

The sensory assessment was performed using the scoring test developed by Kilinc and Cakli (2004). Accurately, 5 panelists evaluated the sensory attributes of Oreochromis Niloticus fillets samples. The fillets samples were blind-coded by special codes; the panelists were not informed about the experimental approach. They were asked to give a score for each of color, odor and consistency while the fillets were raw. The panelists were asked to wash their mouths with warm water between samples.

\section{RESULTS:}

The results obtained in (Table, 1) revealed that, the histamine levels $(\mathrm{mg} \%)$ in examined Oreochromis niloticus fillet samples after addition of essentials oils (1\%) were increased by $24.8 \% ; 70.1 \%$ and $94.5 \%$ with mean values of $18.04 ; 25.67$, and 29.35 after chilling for 3; 6 and 9 days in control samples where, the histamine concentration at zero time was $15.09 \mathrm{mg} / \mathrm{kg}$. Concerning to addition of (cinnamon oil 1\%), levels of histamine decreased to $18.7 \%$; $46.6 \%$ and $77.0 \%$ with mean values of $17.92 ; 22.13$, and 26.71 after 3; 6 and 9 days, respectively; but at zero-time, histamine levels showed no changes since reduction effect of cinnamon oil was not initiated yet.

After addition of oregano oil (1\%), the examined $O$. Niloticus fillet samples, histamine levels showed significant decrease in reduction (\%) $8.2 \%, 23.9 \%$ and $32.3 \%$ with mean values $16.33,18.7$ and 19.96 after 3,6 and 9 days, respectively in storage temperature.in Table(2) stipulated that effect of essential oils (1\%) on sensory traits of treated Reochromis Niloticus fillets Concerning to addition of cinnamon oil, the degree of changes in examined $O$. Niloticus fillet samples were 17.4 (good) after 3 days, but after 6 days 13 (middle); and 10.6 (poor) after 9 days at refrigerator temperature; but with addition of oregano oil, the overall scores were very good (18.4), good (16) and middle (14.4) after 3, 6, and 9 days, respectively at refrigerator temperature. The table also showed that oregano oil gave the best sensory evaluation followed by cinnamon oils.

Table (A): The scoring table for sensory evaluation of fish fillets.

\begin{tabular}{cll}
\hline Score & Grade & Acceptability \\
\hline
\end{tabular}




\begin{tabular}{ccc}
\hline 20 & Excellent & \\
\cline { 1 - 2 } $18.2-19.9$ & Very good & Acceptable \\
\cline { 1 - 2 } $15.2-18.1$ & Good & \\
\hline $11.2-15.1$ & Middle & Border line \\
\hline $7.2-11.2$ & Poor & Unacceptable \\
\hline $4.0-7.1$ & Spoiled &
\end{tabular}

Score * Overall acceptability $=20$ (5 for each of appearance, odor, texture and flavor)

Table (1): Effect of addition of essential oil (1\%) on histamine levels (mg \%) in the examined fillet samples of Oreochromis Niloticus $(\mathrm{n}=5)$.

\begin{tabular}{ccccc}
\hline Storage time $\left(4^{\circ} \mathrm{C}\right)$ & Min & Max & Mean \pm S.E & Progression \% \\
\hline $\begin{array}{c}\text { 1. Control: } \\
\text { Zero time }\end{array}$ & 2.38 & 27.65 & $15.09 \pm 0.43$ & \\
\hline 3 days & 11.76 & 30.13 & $18.84 \pm 0.57$ & 24.8 \\
\hline 6 days & 16.29 & 43.47 & $25.67 \pm 0.81$ & 70.1 \\
\hline 9 days & 18.01 & 51.83 & $29.35 \pm 1.04$ & 94.5 \\
\hline 2. Cinnamon oil $(1 \%):$ & 2.38 & 27.65 & $15.09 \pm 0.43$ & \\
\hline Zero time & 8.63 & 34.40 & $17.92 \pm 0.60$ & 18.7 \\
\hline 3 days & 13.17 & 41.73 & $22.13 \pm 0.74$ & 46.6 \\
\hline 6 days & 15.94 & 46.28 & $26.71 \pm 0.93$ & 77.0 \\
\hline 9 days & 2.38 & 27.65 & $15.09 \pm 0.43$ & \\
\hline 4. Oregano oil $(1 \%):$ & 5.29 & 31.53 & $16.33 \pm 0.49$ & 8.2 \\
\hline Zero time & 7.02 & 34.16 & $18.70 \pm 0.72$ & 23.9 \\
\hline 3 days & 8.98 & 36.41 & $19.96 \pm 0.65$ & 32.2 \\
\hline 6 days & & &
\end{tabular}

Table (2): Changes in sensory traits of control and essential oil treated Oreochromis Niloticus $(\mathrm{n}=5)$.

$\begin{array}{llllll}\text { Character } & \text { Appearance } & \text { Odor } & \text { Texture } & \text { Flavor } & \text { Overall }\end{array}$




\begin{tabular}{ccccccc}
\hline Storage time & $(5)$ & $(5)$ & $(5)$ & $(5)$ & $(20)$ & \\
\hline $\begin{array}{c}\text { 1. Control: } \\
\text { Zero time }\end{array}$ & 5 & 5 & 5 & 5 & 20 & Excellent \\
\hline 3 days & 3.6 & 3.2 & 3.8 & 3.2 & 13.8 & Middle \\
\hline 6 days & 2.2 & 2.0 & 2.2 & 1.8 & 8.2 & Poor \\
\hline 9 days & 1.6 & 1.2 & 1.6 & 1.0 & 5.4 & Spoiled \\
\hline 2. Cinnamon oil: & & & & & & \\
\hline Zero time & 5 & 5 & 5 & 5 & 20 & Excellent \\
\hline 3 days & 4.4 & 4.2 & 4.2 & 4.6 & 17.4 & Good \\
\hline 6 days & 3.2 & 3.2 & 3.4 & 3.2 & 13.0 & Middle \\
\hline 9 days & 2.6 & 2.4 & 2.8 & 2.8 & 10.6 & Poor \\
\hline 4. Oregano oil: & & & & & & \\
\hline Zero time & 5 & 5 & 5 & 5 & 20 & Excellent \\
\hline 3 days & 4.8 & 4.6 & 4.4 & 4.6 & 18.4 & Very good \\
\hline 6 days & 4.4 & 3.6 & 3.8 & 4.2 & 16.0 & Good \\
\hline 9 days & 3.8 & 3.2 & 3.6 & 3.8 & 14.4 & Middle \\
\hline
\end{tabular}

\section{DISCUSSION:}

These results which showed in table (1) were higher than that had been obtained by Cai et al. (2015) who recorded that, highest histamine concentration in examined control samples of fresh fish fillet " $19.41 \mathrm{mg} / \mathrm{kg}$ ", while lower levels were recorded after addition of clove, cumin anpearmint were 2.66, 1.94, and $1.27 \mathrm{mg} / \mathrm{kg}$, respectively. Meanwhile, they were lower than those recorded by Yasser (2016) who reported significant decrease of histamine levels.

From these results, it was concluded that, at zero time the mean value of histamine levels with the progression percentage were still remain as it is not changed after addition of essential oils (cinnamon and oregano oil), which may have attributed to failure of added oils to affect histamine producing bacteria; in addition, added oils could not inhibit bacterial growth.

It was concluded that, the essential oil treatment to the fish fillets caused retardation of fish sensory deterioration signs, and lowered histamine concentrations and decided the fact of Luyun et al. (2015) that addition of essential oils may prolong shelf life of fish meat products and maintaining the quality of fish fillet.

Moreover, Oregano oil was considered the best added essential oil as it was the most reducing oil to histamine levels in examined samples, followed by cinnamon oil and also is more favorable than other oils since it had a good quality with minimum changes in color, odor, and taste of examined samples and also suitable for different consumers.

The antimicrobial effect of oregano and cinnamon is due to carvacol and cinnamaldehyde which are the main 
active princeple causing inhibition to histamine forming bacteria causing reduction of histamine level.

\section{REFERENCES:}

Abobouch, L. (1990): "Histamine in fishery products: a review". FAO Fisheries Report, 4000, supplement, 44-50.

Aishath, N.; Steve, F.; Graham, F.; Phil, B. and Gerrit, M. (2010): "Control of biogenic amines in food existing and emerging approaches". J. Fo

od Sci., 75(7): 139-150.

Amin-Reham, A. A. (2013): "Screening of anti-bacterial activity of cinnamon, clove and rosemary essential oils against common food borne pathogens in minced beef'. Benha Vet. Med. J., 25(2): 151-164.

Cai, L.; Cao, A.; Li, Y.; Song, Z.; Leng, L. and Li, J. (2015): The effects of essential oil treatment on the biogenic amines inhibition and quality preservation of red drum (Sciaenops ocellatus) fillets. J. Food Control, 56: 1-8.

Ercan, S. S.; Bozkurt, H. and Soysal, C. (2013): Significance of Biogenic Amines in Foods and Their Reduction Methods. J. Food Science and Engineering, 3: 395410.

Hungerford, J. M. (2010): "Scombroid poisoning: a review". Toxicol., 56: 231-243.
Kilinc, B. and Cakli S. (2004): "Chemical, microbiological and sensory changes in thawed frozen fillets of Sardine (Sardina pilchardus) during marination". Food Chem., 88: 275-280.

Luyun, C.; Ailing, C.; Yingchang, L.; Zhuo, S.; Liping, L. and Jianrong Jianrong, L. (2015): The effects of essential oil treatment on the biogenic amines inhibition and quality preservation of red drum (Sciaenops cellatus) fillets. J. Food Control, 56: 1-8.

Maintz, L. and Novak, N. (2007): Histamine and histamine intolerance. Am. J. Clin. Nutr., 85:1185-1196.

Tandon, S. and Rane, S. (2008): "Decoction and hot continuous extraction techniques". In: Extraction technologies for medicinal and aromatic plants. Triesto, Italy: ICS-UnIDO; Pp. 93-106.

Tajkarimi, M. M.; Ibrahim, S. A. and Cliver, D. O. (2010): "Antimicrobial herb and spice compounds in food". J. Food Control, 21(1):199-218.

Yasser, M. A. (2016): "Biogenic amines in frozenpoultery and fish". Ph.D. Thesis (Meat Hygiene). Fac. Vet. Med.

Kafr 